\title{
ДОСЛІДЖЕННЯ НОВОГО НАПРЯМКУ В СТВОРЕННІ ЕЛЕКТРОДВИГУНІВ
}

Анотація: В статті наведено фізичне пояснення ефекту Дж. Губера, а саме виникнення обертового моменту рухомої колісної пари за умови проходження електричного струму через точку дотику колеса до направляючої. Запропоновано нові конструкції колісної пари, як основного елемента електродвигунів, в яких має місто не нульовий пусковий момент.

Ключові слова: ефект Губера, електродвигун, закон Ампера, пусковий момент.

\section{Вступ}

Інженером Дж. Губером в 1959 році для колісної пари, що котилася по залізним рейкам, за умови пропускання електричного струму через місце дотику колеса до направляючої, було виявлено додаткову силу у напрямку швидкості руху. Подібний ефеккт В 1961 році спостерігався В.В. Косаревим, В.Д. Рябко, В.І.Вельманом для роликових, а в 1967 році Р.А. Мільроєм - для кулькових підшипників. В усіх дослідах сила нелінійно залежала від швидкості обертання і була відсутня при запуску. Півстоліття автори робіт $[1,2,3,4]$ намагалися дати пояснення цьому ефректу. Велику роботу по вивченню та узагальненню дослідів цих авторів та самого Дж. Губера здійснено профресором А.В.Нетушилом [2]. Однак досвід та наукова інтуїція А.В.Нетушила, який очолював в той час комітет по розслідуванню винаходів, які не мають чіткого фізичного пояснення, говорив про необхідність подальших досліджень цього ефректу.

Так при обговорюванні ефекту Губера було висловлено дві гіпотези [2]: це тепловий ефект розширення матеріалу направляючої в місці контакту (як би гірка позаду точки дотику) або силова дія іскрового розряду в місці відриву колеса або кульки від направляючої. Природно, що обидва ефректи мають місце, але наскільки вони суттеві? В.В. Кузьмін та В.С. Шпатенко [5] вперше (хоча це очевидно) подали гіпотезу, з якої витікае, що струм від контакту колеса з направляючою рухається по дещо викривленій траєкторії, не радіальна складова якої за законом Ампера взаємодіє зі струмом направляючої, утворюючи відштовхуючу силу позаду від точки дотику, яка й створює обертовий момент. Елементарні розрахунки швидкості направленого руху електронів від точки дотику колеса до вісі та швидкості переносу їх у просторі колесом, що обертається, показують [6], що навіть за невеликих кутових швидкостей, траєкторії струмів у колесі - це багатовиткові спіралі. Це призводить до

(c) А.М. Сільвестров, В.В. Піксотов, Д.К. Зіменков, 2013 
збільшення сил Ампера з правого та лівого боку від точки дотику колеса до направляючої і, відповідно, обертового моменту.

В системі “підшипник-вал” для створення сили Ампера та моменту, що обертає кульки, необхідно щоб магнітний потік, як і струм, проходив би через кульки, а не замикався навколо струму. Тому у роботах [4] Г.В. Ніколаева і С.С. Воронкова для пояснення ефекту Губера довелося відійти від вихрової властивості магнітного поля до прямолінійної, що суперечить природі магнетизму.

Детальний розгляд цієї системи [6] показав, що через вал який обертається, струм проходить по спіралі, як в котушці зі струмом. Тому магнітний потік буде осьовим для вала та співпадаючим зі струмом через підшипник, зберігаючи при цьому вихрову природу.

Природну властивість мінімізації активної потужності втрат електромагнітних систем було використано M.I. Граммом [3] для спроби пояснення ефекту Губера, зокрема нелінійної залежності моменту від швидкості.

Модуляція повітряного зазору підшипників рухомими кульками призводить до модуляції магнітного потоку, що, відповідно до закону електромагнітної індукції, наводить індукційні струми кульок, які за законом Ампера взаємодіють з магнітним потоком [6]. Це також створює, якусь частину загального моменту в підшипниках.

\section{Постановка задачі}

Виходячи з аналізу проведених досліджень перед авторами статті постала задача подальших теоретично-експериментальних досліджень з метою визначення головної складової обертового моменту в ефекті Губера і вдосконалення конструкції колісної пари Губера з метою створення не нульового пускового моменту, що важливо для практичного використання цього ефекту в електродвигунах.

\section{Вирішення задачі}

Як показали дослідження [6], в колесі чи кульці має місце не легке, а суттєве викривлення траєкторії струму між точкою дотику колеса чи кульки підшипника до направляючої і віссю колеса чи протилежною точкою дотику кульки до направляючої. Навіть за не великих кутових швидкостей обертання колеса, траєкторія потоку електрики в колесі - це спіраль і чим більша швидкість обертання, тим більша кількість витків цієї спіралі в колесі.

Пояснимо це на прикладі колеса (рис. 1), яке котиться по направляючій, підключеній до мінусової клеми джерела струму, а вісь колеса через друге колесо колісної пари підключено до плюса джерела.

Напруженість $\varepsilon$ електричного поля в колесі пропорційна електричному опору відповідної ділянки колеса на шляху потоку еле- 


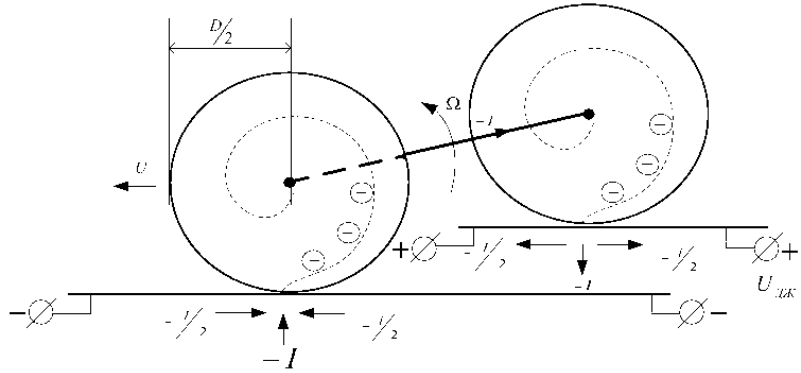

Рис. 1 - Ефрект Дж. Губера

ктрики від точки дотику до осі. Вона найбільша в точці дотику, де опір максимальний, потім зменшуеться, так як збільшуеться площа поперечного перетину в колесі (зменшуеться його опір) i, наближаючись до осі дещо зростає. Під дією напруженості $\varepsilon$ утворюеться направлений від точки дотику до осі потік вільних електронів (струм $I$ провідності зі знаком мінус). Під дією максимальної в точці дотику колеса до направляючої напруженості $\varepsilon_{\max }$, електрони з направляючої попадають в тіло колеса утворюючи надлишок електронів в зоні дотику (ефект, подібний до електризації). Точка дотику, внаслідок обертання колеса, переміщуеться по його окружності з лінійною швидкістю $\Omega D / 2$, де $D$ - діаметр колеса, $\Omega$ - кутова швидкість. Відповідно, в тілі колеса переміщуеться електричне поле, утворене зовнішнім джерелом струму. Тоді, до моменту повного оберту колеса, вкинуті напруженістю $\varepsilon_{\max }$ заряди $q$, створюють своє електричне поле між ними і віссю, під дією якого вони продовжують рухатись до осі колеса, створюючи струм провідності густини - $j_{n p}$, яка дорівнюе $\gamma \varepsilon(x)$, де $\gamma$ - питома провідність тіла колеса, $x$ - відстань до осі. Тобто, в системі координат, прив'язаної до тіла колеса, має місце радіально направлений рух вільних електронів від окружності до осі зі швидкістю $U_{1}=\beta \varepsilon(x)$, де $\beta-$ коефріцієнт рухомості вільних електронів. В системі координат з початком на осі колеса, осями паралельними і перпендикулярними направляючим, до струму провідності додається струм переносу зарядів колесом, що обертається. Його густина $j_{\text {nep. }}$ дорівнюе $\rho V_{2}(x)$, де $\rho$ - об'емна щільність заряду $q, V_{2}(x)=\Omega x$ - лінійна швидкість.

За реальних напруженості $\varepsilon(x)$ і кутової швидкості $\Omega$, швидкість $V_{1}$ набагато менша $V_{2}$. Тому загальний потік електрики в колесі має спіралеподібну траєкторію. Зі зростанням $\Omega$ кількість “витків" спіралі струму зростає. Це призводить до накопичення негативного заряду поблизу окружності колеса. В результаті зменшуеться різниця потенціалів між направляючою і окружністю колеса, зменшуеться $\varepsilon_{\max }$, зменшуеться струм $I$ джерела напруги і, від- 
повідно, (подібно до моменту однофазного асинхронного двигуна) зменшуеться обертовий момент, що і було виявлено в експериментах $[1,3]$.

Таким чином, обертовий момент в двигуні Губера створюеться від магнітної взаємодії струму переносу зарядів в колесі зі струмом направляючої. Справа від точки дотику ці струми направлено зустрічно, що (згідно з законом Ампера) їх відштовхуе; зліва - в одному напрямку, що їх притягуе. Це створюе пару сил відносно точки дотику колеса до направляючої. В другому колесі колісної пари Гувера ефект аналогічний: справа від точки дотику струми направлено назустріч, зліва - в одну сторону.

В роликовому чи кульковому підшипнику між точками дотику ролика чи кульки до двох направляючих, внаслідок тих же причин, траєкторія струму викривляеться, наближаючись до напівокружності діаметра ролика чи кульки.

Двигун Дж. Губера складаеться (рис. 2) з колісної пари 2 і направляючих 3 , до яких підведено напругу $U$ від джерела електроенергії 4.

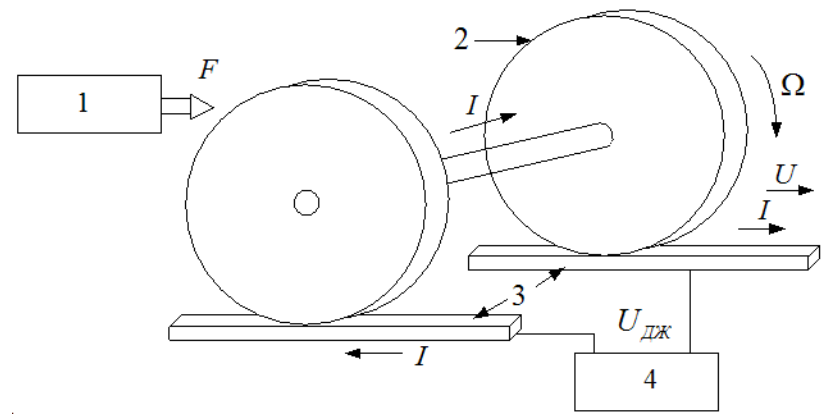

Рис. 2 - Система з двигуном Дж. Губера

Якщо колісній парі 2 від стороннього механічного приводу 1 надати початковий рух імпульсом сили $F$, то далі колісна пара буде рухатись без приводу 1 зі швидкістю $V=D / 2 \Omega$, яка залежить від квадрата струму $I$, протидіючого моменту, діаметру $D$, речовини колеса і направляючих та ін.. Змінити напрямок руху такої колісної пари можливо лише зупинивши їі і подавши імпульс сили $F$ в протилежному напрямку.

Удосконалену конструкцію колісної пари (рис. 3), з метою створення пускового моменту та простого реверса руху, складено з колісної пари 1 , направляючих 2 , джерела струму 3 . Але колеса колісної пари 1 мають розрізаний зазором 4 феромагнітний обід 5 , електрично ізольований від тіла колеса ізоляційним матеріалом 6 і електрично з'еднаний з провідником у валу 7 двома провідника- 
ми 8,9 через перемикач 10 , який залежно від бажаного напрямку руху замикає один із контактів провідників 8 чи 9.

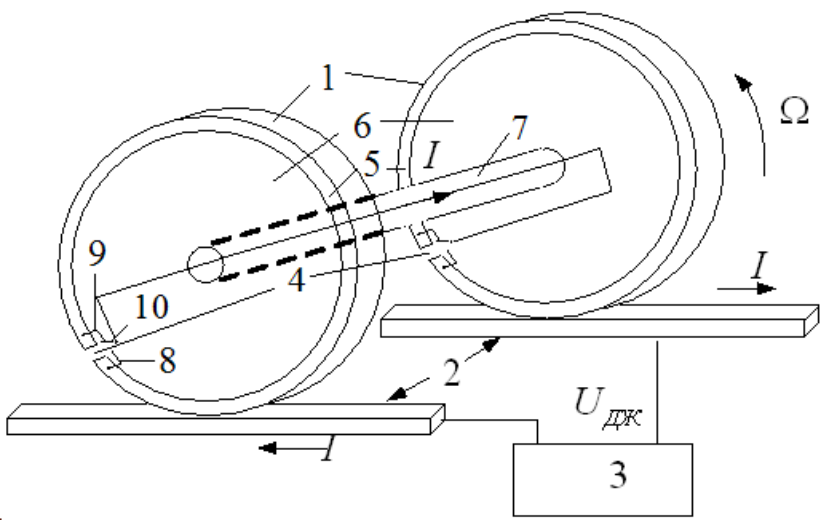

Рис. 3 - Система з удосконаленим двигуном Дж. Губера

Наприклад, якщо замкнено контакт 9 і зазор 4 в момент пуску не співпадає з точкою дотику колеса до направляючої, то між зустрічно направленими у просторі струмами направляючої 2 і обода 5 завдяки взаємодії їх магнітних полів, виникає сила відштовхування, що приводить до початку обертання колеса проти часової стрілки. I навпаки, якщо замкнено контакт 8, сила взаємодії струму виникає зліва від точки дотику і напрямок обертання колеса буде протилежним. Сдине положення колеса відносно направляючої, за якого струми колеса і направляючої не взаємодіють і обертовий момент відсутній, це якщо точка дотику співпадає з точкою підключення провідника замкненого контакту ( на рис. 3 це контакт 9). Ймовірність такого положення дуже мала. Однак, як правило у двигуні використовують, як мінімум, дві колісних пари із різним розташуванням зазору 4 або навіть одну з різним положенням зазору у колесах. Це повністю виключає ситуацію з нульовим пусковим моментом. Взагалі, у конструкції двигуна можлива електронна комутація перемикача 8,9,10.

Окрім того, повздовжній рух можна замінити на обертовий, якщо направляюча буде кільцем, а вали колісних пар будуть механічно з'єднані з загальним валом.

Чим менше відстань між колесом і направляючою в зоні дотику, тим сильніша взаємодія струмів і, відповідно, момент. Тому для створення якомога більшого моменту можлива конструкція двигуна з близькими діаметрами направляючої і колеса та спільним колінчатим валом (рис. 4), який переводить рух по направляючій в обертовий рух головного вала. 


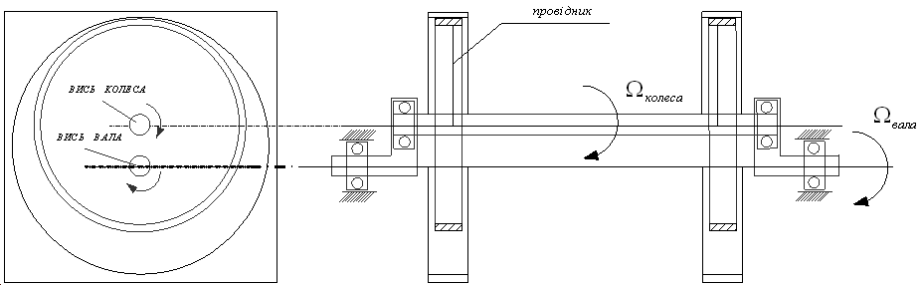

Рис. 4 - Система з колінчатим валом

За обмеженого приварюванням колеса до направляючої струму $I$, пусковий і робочий моменти можна збільшити шляхом використання паралельно ввімкнених декількох колісних пар.

Шоб не збільшувати загальний струм джерела струму, а збільшити напруги джерела, слід $n$ колісних пар з направляючими ввімкнути відносно джерела послідовно. Можливий також варіант змішаного включення (Рис.5) колісних пар.

На креслені (рис. 5) подано повздовжній і поперечний перетин двигуна, побудованого з колісних пар (рис. 3), в якому, як приклад, маємо 3 паралельних вітки, в кожній з яких послідовно ввімкнено 4 колісні пари. Таке з'єднання дозволяє в 3 рази зменшити струм колісних пар і в 4 рази збільшити напругу джерела електроживлення двигуна. Тоді за обмеження приварюванням колісних пар до направляючих, пусковий момент порівняно з однією колісною парою зросте в 12 разів. При підключенні однієї з двох паралельних віток проводок 8,9 (рис. 3) перемикачем 13 до джерела живлення, струм $I$, проходячи через контакти розрізаних ізольованих кілець (рис. 3) і направляючих, утворює обертовий момент. Під його дією колісні пари рухаються по кільцевим направляючим, передаючи повздовжній рух своєї осі в обертовий рух головного валу 1 . Перемикачі 13 (рис. 5) та 8,9,10 (рис. 3) можуть бути як контактними, так і електронними, з ручним або дистанційним електромагнітним керуючим органом 13 (рис. 5). Вони розташовані в трубчастих валах 5 (рис. 6) колісних пар і під дією керуючого органа 13 (рис. 5) переключають контакти 8,9,10 (рис. 3), якщо виникає необхідність в реверсі.

\section{Експериментальне підтвердження виникнення пускового моменту}

При підключенні струму $I=5 A$ до направляючих колісна паpa (рис. 3) починала рух із стану спокою. Щоб наближено розрахувати пусковий момент $M$ скористаємося законом Ньютона для лінійного $m a=F=M / D / 2$ або кутового $J \frac{d \Omega}{d t}=M$ рухів, де $m, J$ - маса або момент інерції колісної пари; $a, \frac{d \Omega}{d t}-$ лінійне або кутове прискорення. За нульових початкових умов, двічі проінтегрувавши ці рівняння, отримаємо $m x=\frac{M}{D / 2} \frac{t^{2}}{2}$ або $\varphi=\frac{M}{I} \frac{t^{2}}{2}$, де для кон- 


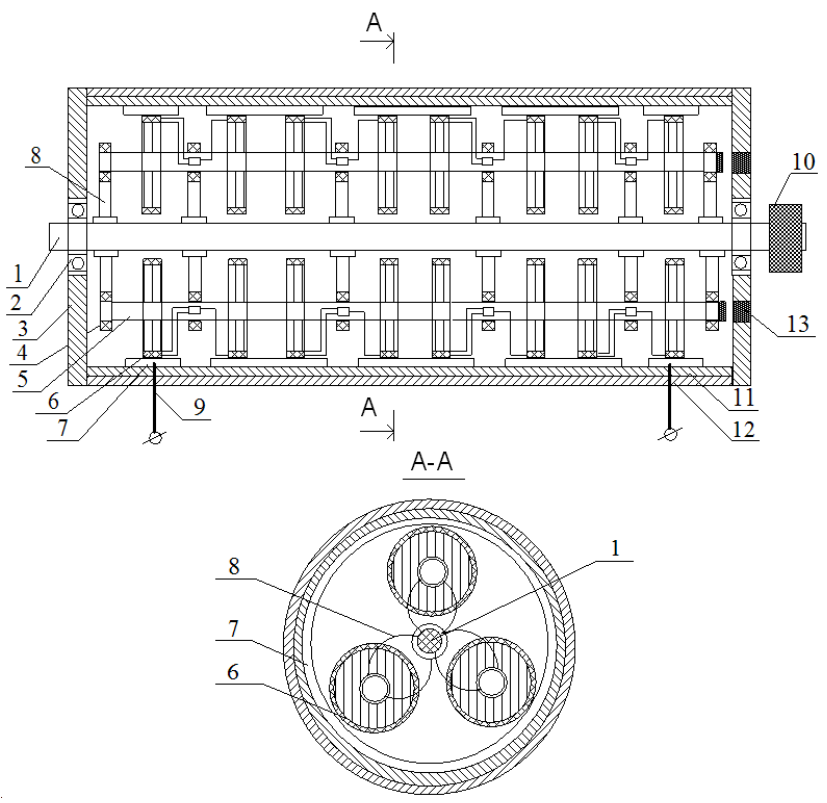

Рис. 5 - Змішане включення колісних пар, де: 1 -- головний вал, 2 - підшипники головного валу, 3 - металеві торцеві частини корпуса, 4 -- підшипники спільного трубчастого валу 5 колісних пар 6,7 -- направляючі колісних пар, 8 - пружні кріплення підшипників 4 до головного валу, 9 -- ізольована проводка струму від одного полюса джерела через контакти “колеса - направляючі” до другого, 10 - муфта, 11 -- ізоляційний циліндр, 12 -- металевий циліндр корпуса, 13 - електромагнітний перемикач жил проводки від обода 5 до осі 7 колісних пар (рис. 3)

кретних даних експерименту (маса $m=0,4$ кг, шлях $x=0,075 \mathrm{м}$, кут $\varphi=\pi$ радіан, $t \cong 1$ сек., діаметр $D=0.1$ м) момент Мза обома формулами, враховуючи наближеність склав $0.006 \pm 0.001 \mathrm{Hм.}$ Згідно до закону Ампера сила взаємодії $i$, відповідно, момент пропорційні добутку струмів, а в даному випадку квадрату струму. Так для струму $I=50$ А пусковий момент складе вже 0,628 Нм. Далі, за наявності не нульової кутової швидкості $\Omega$, струм і, відповідно, момент можна ще збільшити, так як точка дотика колеса до направляючої постійно зміщуеться, що запобігає приварюванню колеса до направляючої. Використання $n$ колісних пар та більш якісного феромагнетика збільшить (за того ж струму в контакті) момент більше ніж в $n$ разів. 


\section{Висновок}

Таким чином, в результаті аналізу 50-річних досліджень ефекту Дж. Губера різними вченими [1-6], вдалося з'ясувати його природу, удосконалити колісну пару Дж. Губера і запропонувати конструкції електродвигунів нового типу, в основу яких покладено модифіковані колісні пари (рис. 3). Такі електродвигуни можуть бути побудовані з недорогих пластмасових матеріалів та невеликої кількості феромагнетиків. Електродвигуни на базі колісних пар (рис. 4) об'єднують у собі і редуктори, що також суттево спрощуе їх конструкцію та вартість. Можливий подальший розвиток даного напрямку досліджень полягатиме в розробці феромагнітної рідини з високими магнітною проникністю та електричним опором. Наявність такої рідини замість повітря в зоні контакту коліс і направляючих суттево збільшить обертовий момент колісної пари Дж. Губера. Можливо також використання кривошипно-шатунного механізму для перетворення повздовжніх коливань модифікованої колісної пари (рис. 3) в обертовий рух.

\section{Біблиографічний список}

1. Поливанов К.М, Татаринова Н.В., Нетушил А.В. Электромеханический эффект Губера. Электричество. - 1973 - -№8 - 72-76с.

2. Нетушил А.В. Изобретение Дж.Серла, как развитие эфффекта Губера . Электричество - 1994 - №4 - 50-53 с.

3. Грамм М.И. Принцип минимума и возможные объяснение эффректа Губера. Электричество - 2002 - №12 - 57-60 с.

4. Николаев Г.В. Современная электродинамика и причины ее пародоксальности. Томск: Твердыня - 2003-149 с.

5. Кузьмин В.В., Шпатенко В.С. О природе появления вращающего момента в двигателе Косырева-Мильроя. Вісник КДРУ ім.Остроградського - 2008 - №3 - 41-47 с.

6. Сильвестров А.Н., Зименков Д.К. О природе эффректа Губера. Вісник КДУ ім.Остроградського-2010 - №4 - 33-38 с.

Отримано 13.10.2013 p. 